\title{
Pelaksanaan Layanan Bimbingan Belajar Pada Siswa Kelas IV SD Negeri 58 Tambana Tahun Ajaran 2019/2020
}

\author{
Subhan \\ STKIP Taman Siswa Bima \\ subhantanjung@gmail.com
}

Artikel Info

$\underline{\text { Tanggal Publikasi }}$

2021-06-30

$\underline{\text { Kata Kunci }}$

Layanan Bimbingan

Belajar

Bimbingan Belajar.

\section{Abstrak}

Penelitian ini bertujuan untuk mendeskripsikan pelaksanaan serta hambatan pelaksanaan layanan bimbingan belajar di kelas IV Negeri 58 Tambana. Metode penelitan ini menggunakan pendekatan kualitatif dengan subjek penelitian guru kelas IV. Instrumen penelitian yang digunakan adalah wawancara, dokumentasi, observasi, catatan lapangan dan angket. Langkah-langkah analisis data meliputi reduksi data, penyajian data, dan verifikasi. Hasil penelitian menunjukkan bahwa guru belum membuat program layanan bimbingan belajar. Layanan bimbingan belajar dilaksanakan oleh guru sesuai dengan pemahamannya. Layanan bimbingan belajar oleh guru dipahami sebagai suatu bentuk bantuan bagi siswa untuk mencapai hasil belajar sesuai target yang ditetapkan. Dalam melaksanakan layanan bimbingan belajar, guru mengalami hambatan antara lain keterbatasan pemahaman, waktu, serta keterampilan.

\section{PENDAHULUAN}

Alasan peneliti memilih judul "Pelaksanaan Layanan Bimbingan Belajar Pada Siswa Kelas IV SD Negeri 58 Tambana Tahun Ajaran 2019/2020” karna peneliti ingin mengetahui, bagaimana pelaksanaan serta hambatan layanan bimbingan belajar pada siswa kelas IV SD Negeri 58 Tambana. Serta mengkaji lebih dalam hal pelaksanaan layanan bimbingan belajar. Pemilihan kelas IV ini berdasarkan beberapa alasan antara lain: 1) Anjuran dari kepala sekolah untuk meneliti kelas tinggi agar lebih mudah dalam komunikasi; 2) Disarankan untuk tidak meneliti kelas VI karena sedang fokus persiapan menghadapi ujian; 3) Rata-rata nilai kelas pada kelas IV SD Negeri 58 Tambana lebih rendah dibanding dengan kelas-kelas yang lain yaitu 72; dan 4) Guru wali kelas IV mendapat teguran dari kepala sekolah dan guru-guru yang lain terkait rendahnya nilai rata-rata kelas.

Sekolah dasar merupakan jenjang pendidikan yang dijadikan pondasi untuk mewujudkan tujuan pendidikan nasional yaitu berkembangnya peserta didik agar menjadi manusia yang beriman dan bertakwa kepada Tuhan Yang Maha Esa, berakhlak mulia, sehat, berilmu, cakap, kreatif, mandiri, dan menjadi warga negara yang demokratis serta bertanggung jawab (UU No. 20 tahun 2003). Untuk mewujudkan tujuan tersebut, maka perlu mengintegrasikan seluruh komponen yang ada dalam pendidikan, salah satunya adalah komponen bimbingan dan konseling. Hal ini juga diungkapkan oleh Juntika (Tohirin, 2009: 12) bimbingan merupakan bagian integral dari proses pendidikan dan memiliki kontribusi terhadap keberhasilan proses pendidikan. Bimbingan dan konseling merupakan suatu perangkat penting dalam dunia pendidikan. Kedudukan layanan bimbingan dan konseling di sekolah dasar dalam sistem pendidikan di Indonesia sudah diatur dan dibicarakan khusus dalam Permendikbud Nomor 11 Tahun 2014 pasal 10 ayat (1) yang berbunyi: Penyelenggaraan bimbingan dan konseling pada SD/MI atau yang sederajat dilakukan oleh konselor atau guru bimbingan dan konseling.

Latar belakang perlunya bimbingan dan konseling di sekolah dasar karena adanya kesadaran akan perlunya sistem pengajaran dan pelayanan kependidikan yang berpusat pada kebutuhan dan 
karakteristik peserta didik. Bimbingan dan konseling perlu diberikan kepada siswa sekolah dasar karena sebagai individu yang telah berkembang, siswa tidak bisa luput dari tekanan dari dalam diri dan tuntutan dari lingkungannya. Dalam upaya mencapai tugas-tugas perkembanganya, siswa tidak cukup diberi pengajaran saja, tetapi juga perlu mendapat bantuan yang bersifat individual untuk dapat mengembangkan seluruh potensi yang dimiliki secara optimal (Badarudin, 2011: 1).

Prayitno dan Amti (2010: 105) konseling adalah proses pemberian bantuan yang dilakukan melalui wawancara konseling dengan seorang ahli (disebut konselor) kepada individu yang sedang mengalami sesuatu masalah (disebut klien) yang bermuara pada teratasinya masalah yang dihadapi klien.

Mekanisme pengelolaan layanan bimbingan dan konseling di satuan pendidikan diatur dalam Permendikbud Nomor 11 Tahun 2014 pasal 8 ayat 2 yang meliputi langkah: analisis kebutuhan, perencanaan, pelaksanaan, evaluasi, pelaporan, dan tindak lanjut pengembangan program. Seperti yang sudah dijelaskan dalam Permen pasal 10 ayat 1, pelaksanaan layanan bimbingan dan konseling dilakukan oleh konselor atau guru bimbingan dan konseling akan tetapi layanan bimbingan dan konseling di sekolah dasar untuk saat ini masih dilaksanakan oleh guru kelas khususnya di SD Negeri 58 Tambana. Pelaksanaannya terpadu dalam proses pembelajaran sehingga proses pembelajaran menjadi wahana atau tempat bagi layanan bimbingan di sekolah dasar baik bimbingan belajar, pribadi, sosial, dan karir baik untuk anak berbakat, anak dengan kesulitan belajar, maupun anak dengan perilaku bermasalah.

Salahudin (2010: 7) mengartikan bimbingan sebagai proses pemberian bantuan, terutama dari aspek psikologi yang dilakukan oleh seorang ahli kepada siswa-siswa peserta didik dalam memahami dirinya, dan menghubungkan dengan lingkungannya, serta memilih, menentukan, dan menyusun rencana sesuai dengan konsep diri yang dituntut lingkungan berdasarkan norma-norma yang berlaku. Lebih lamjut Achmad dan Sudianto (2012: 8) menjelaskan bahwa bimbingan dan konseling perkembangan di SD merupakan sebuah upaya pemberian bantuan kepada individu (peserta didik/siswa) yang dilakukan secara berkesinambungan, supaya mereka dapat memahami dirinya sehingga mereka sanggup mengarahkan dirinya dan dapat bertindak secara wajar sesuai dengan tuntutan dan keadaan lingkungan SD, keluarga, dan masyarakat serta kehidupan pada umumnya.

Pendapat yang sama juga dikemukakan oleh Hikmawati (2011: 4-5) yang berpendapat bahwa layanan bimbingan belajar ialah layanan mengoptimalkan perkembangan dan mengatasi masalah dalam proses pembelajaran bersama guru dan belajar mandiri baik di rumah maupun di sekolah. Dari berbagai pendapat di atas dapat disimpulkan bahwa layanan bimbingan belajar merupakan suatu proses bantuan yang diberikan kepada individu (siswa) untuk dapat mengatasi masalah belajar yang dihadapinya baik di sekolah maupun di rumah sehingga mereka mampu berkembang dan mencapai prestasi belajar yang optimal.

Peneltian terdahulu yang serupa dengan penelitian ini adalah penelitian yang dilakukan oleh: M. Nurul Iman (2015) "Penggunaan Layanan Bimbingan Kelompok Untuk Meningkatkan Motivasi Belajar Pada Siswa Kelas VIII SMP Negeri 1 Bandar Sribhawono Kabupaten Lampung Timur Tahun Ajaran 2015/2016. Masalah dalam penelitian ini motivasi belajar siswa rendah. Tujuan penelitian ini adalah untuk mengetahui bahwa layanan bimbingan kelompok dapat dipergunakan untuk meningkatkan motivasi belajar pada siswa kelas VIII SMP Negeri I Bandar Sribahawono Kabupaten Lampung Timur. Metode yang digunakan dalam penelitian ini metode pre eksperimen dengan desain one group pretest-posttest, dan dianalisis dengan menggunakan uji Wilcoxon. Subyek penelitian 11 orang siswa kelas VII SMP Negeri I Bandar Sribahawono Kabupaten Lampung Timur yang memiliki motivasi belajar yang rendah. Teknik yang digunakan dalam pelaksanaan layanan bimbingan kelompok pada penelitian ini adalah teknik informasi, diskusi dan homeroom. Hasil analisis data dari pretest dan posttest motivasi belajar pada siswa menggunakan uji beda Wilcoxon, diperoleh z hitung -2, $446<z$ tabel 1,645, maka Ha diterima, artinya layanan bimbingan kelompok dapat dipergunakan 
untuk meningkatkan motivasi belajar pada siswa kelas VIII SMP Negeri I Bandar Sribhawono tahun ajaran 2015/2016.

Tujuan dari penelitian ini adalah untuk mengetahui sejauhmana pelaksanaan layanan bimbingan belajar pada siswa kelas IV SD Negeri 58 Tambana, serta bagaimana kelebihan dan kekurangan pelaksanaan bimbingan belajar tersebut.

\section{METODE PENELITIAN}

Penelitian ini menggunakan jenis penelitian kualitatif. Menurut Lexy J. Moleong (2012: 6), penelitian kualitatif adalah penelitian yang bermaksud untuk memahami fenomena tentang apa yang dialami oleh subjek penelitian misalnya perilaku, persepsi, motivasi, tindakan, dan lain-lain yang dilakukan secara holistik dan dengan cara deskripsi dalam bentuk kata-kata dan bahasa pada suatu konteks khusus yang alamiah dan dengan memanfaatkan berbagai metode ilmiah. Dalam penelitian ini, peneliti mengumpulkan data deskriptif yang diperoleh dari pengumpulan data dengan pendekatan kualitatif yang dituangkan dalam bentuk kata-kata.

Instrumen pengumpulan data yang digunakan oleh penulis adalah: Pedoman interview, pedoman observasi, dan catatan dokumentasi. Adapun tenik pengumpulan data atau langkah-langkah pengumpulan data yang akan dilakukan oleh peneliti guna mendapatkan data yang memenuhi standar data yang ditetapkan, adalah sebagai berikut: (a) Perencanaan, termasuk dalam kegiatan ini adalah menyusun draft penelitian, termasuk menyusun instrumen penelitian, penentuan lokasi, pengurusan perizinan serta kegiatan lain yang bersifat administratif. (b) Pelaksanaan penelitian/pengumpulan data, yaitu mengumpulkan data di lapangan (objek penelitian) untuk diolah, dianalisis, dan disimpulkan. Dalam hal ini pengumpulan data dilakukan dengan observasi, wawancara, serta Dokumentasi. (c) Pengolahan data, dilakukan setelah peneliti selesai mengumpulkan data. Teknik pengolahan data pada penelitian ini menggunakan analisis deskriptif kualitatif melalui tiga tahap yaitu: reduksi data, penyajian data (display data) dan verifikasi data atau penarikan kesimpulan. Penyusunan laporan penelitian. Kegiatan ini merupakan finalisasi penelitian dengan menuangkan hasil pengolahan, analisis data, dan kesimpulan tersebut dalam bentuk tulisan yang disusun secara sistematis.

Teknik Analisis Data. Pengolahan data dalam penelitian ini menggunanakan analisis deskriptif kualitatif, yakni penyusunan data-data kemudian dijelaskan dan dianalisis serta dilakukan bersamaan dengan pengumpulan data. Proses pengolahan data mengikuti teori Miles dan Huberman, sebagaimana yang dikutip oleh Sugiyono, bahwa proses pengolahan data melalui tiga tahap, yaitu reduksi data, penyajian data (display data) dan verifikasi data atau penarikan kesimpulan.

\section{HASIL DAN PEMBAHASAN}

Pelaksanaan bimbingan dan konseling belum berjalan secara optimal. Hal ini terbukti dari adanya beberapa masalah yang berhubungan dan memerlukan penanganan layanan bimbingan dan konseling khususnya masalah belajar yang dialami siswa kelas IV SD Negeri 58 Tambana. Untuk menangani masalah belajar perlu pelaksanaan layanan bimbingan dan konseling bidang bimbingan belajar. Maka dari itu, peneliti ingin mendalami lebih jauh tentang bagaimana pelaksanaan layanan bimbingan belajar pada siswa kelas IV SD Negeri 58 Tambana. Hasil wawancara tersebut adalah sebagai berikut:

Pertama, banyak masalah belajar yang dialami oleh siswa kelas IV SD Negeri 58 Tambana seperti kurang motivasi dalam belajar, sikap dan kebiasaan yang buruk dalam belajar, sering tidak masuk sekolah, suka mengganggu teman ketika proses pembelajaran sedang berlangsung, belum bisa membaca, dan lain-lain. Dengan masuk ke sekolah dasar, diharapkan anak mampu mengikuti proses pembelajaran dan pendidikan dengan baik serta mampu menambah kemampuan kognitif, afektif, dan psikomotornya. Akan tetapi tidak selalu demikian seperti yang diharapkan orang tua maupun 
guru. Dari segi usia mungkin mereka sama, tetapi dari sisi kemampuan tidak semuanya sama. Banyak faktor yang menyebabkan kemampuan setiap peserta didik berbeda, seperti kemampuan intelektual, minat belajar, sikap, motivasi diri, latar belakang keluarga dan lain-lain. Untuk mengatasi masalahmasalah ini perlu ditangani melalui program bimbingan dan konseling yang baik disertai dengan pelaksanaannya yang benar khususnya bidang bimbingan belajar supaya masalah belajar yang dihadapi peserta didik serta tugas-tugas perkembangannya dapat ditangani dengan optimal. Kedua, guru kelas lebih mementingkan penyampaian materi ajar sehingga pelaksanaan bimbingan dan konseling khususnya layanan bimbingan belajar kurang mendapat porsi yang memadai. Padahal tugas dan tanggung jawab guru kelas di sekolah dasar selain mengajar juga bertanggung jawab melaksanakan bimbingan dan konseling. Dengan demikian selain mengajar, guru harus memperhatikan karakteristik siswanya sebagai bekal dalam menentukan jenis layanan yang akan diberikan khususnya layanan bimbingan belajar dalam mengatasi masalah belajar yang dihadapi oleh siswa. Ketiga, pelaksanaan layanan bimbingan dan konseling di kelas IV SD Negeri 58 Tambana mengalami kendala keterbatasan waktu. Masalah tersebut disampaikan langsung oleh guru wali kelas IV pada saat diwawancarai oleh peneliti. "Hal ini terjadi karena pelaksanaan layanan bimbingan dan konseling terpadu dalam proses pembelajaran. Dengan pemikiran seperti itu tugas guru akan terbatas dan konsekuensinya pelayanan bimbingan akan terabaikan. Padahal tugas pokok guru dalam melaksanakan bimbingan dan konseling sudah jelas yaitu menyusun, melaksanakan, dan mengevaluasi pelaksanaan bimbingan. Hal tersebut menjadi alasan mengapa pelayanan bimbingan dan konseling di sekolah dasar kurang berjalan dengan baik".

Hasil penelitian menunjukkan bahwa di SD Negeri 58 Tambana belum disusun program layanan bimbingan belajar, secara operasional layanan bimbingan belajar di SD Negeri 58 Tambana dilaksanakan oleh guru kelas yang terpadu dengan proses pembelajaran. Sehingga peran, fungsi serta tanggung jawab guru kelas tidak hanya sebagai pengajar tetapi juga sebagai seorang pembimbing. Sebenarnya temuan ini tidak sesuai dengan peraturan terbaru tentang pelaksanaan bimbingan dan konseling yang dikeluarkan oleh kementrian pendidikan dan kebudayaan RI. Dalam Permendikbud nomor 11 tahun 2014 pasal 10 ayat 1 berbunyi: penyelenggaraan bimbingan dan konseling pada $\mathrm{SD} / \mathrm{MI}$ atau yang sederajat dilakukan oleh konselor atau guru bimbingan dan konseling.

Akan tetapi karena belum memiliki guru bimbingan dan konseling, pelaksanaan layanan bimbingan tetap diberikan oleh guru kelas Jenis kegiatan yang dilakukan guru dalam memberikan layanan bimbingan belajar menggunakan pengajaran perbaikan dan pengayaan. Guru kelas IV menggunakan pengajaran perbaikan untuk siswa atau sekelompok siswa yang nilainya belum mencapai standar KKM tiap mata pelajarannya. Sedangkan pengayaan diberikan untuk siswa yang nilainya sudah di atas standar KKM untuk memperkaya materi memperluas pengetahuan.

Temuan dari data penelitian menyatakan bahwa pihak sekolah terutama kepala sekolah dan guru belum mempersiapkan fasilitas dan biaya pelaksanaan layanan bimbingan. Akan tetapi jika dibutuhkan, pihak sekolah akan mempersiapkan fasilitas serta biaya yang dibutuhkan. Salah satu tugas kepala sekolah adalah menyediakan dan melengkapi sarana dan prasarana, tenaga, dan berbagai kemudahan lainnya bagi terlaksananya program bimbingan dan konseling yang efektif dan efisien. Sebenarnya fasilitas dan biaya merupakan salah satu faktor pendukung terlaksananya program layanan bimbingan.

Deskripsi hasil penelitian menunjukkan bahwa layanan bimbingan belajar yang diberikan kepada siswa kelas IV dalam bentuk pengajaran perbaikan bertujuan untuk memperbaiki hasil belajar yang telah diraih siswa. Yang dimaksud memperbaiki hasil belajar di sini adalah untuk membantu siswa atau sekelompok siswa agar nilai yang didapatkannya mencapai KKM yang telah ditentukan. Pengajaran perbaikan dilakukan kepada seseorang atau sekelompok murid yang menghadapi masalah belajar dengan maksud untuk memperbaiki kesalahan dalam proses dan hasil belajar mereka. Meskipun tujuan dari diberikannya perbaikan untuk memperbaiki hasil belajar siswa itu sudah tepat, akan tetapi dalam pelaksanaannya belum sepenuhnya sesuai konsep. Seperti yang dijelaskan oleh 
Sunaryo Kartadinata di atas bahwa perbaikan diberikan kepada seseorang atau sekelompok siswa. Namun ketika melaksanakan pengajaran perbaikan, guru memberikannya untuk semua siswa kelas IV. Guru belum memberikan bimbingan dan perbaikan secara khusus untuk siswa yang benar-benar membutuhkan pengajaran perbaikan. Selain itu guru hanya memberikan ulangan ulang ketika diadakan perbaikan.

Berdasarkan data yang didapat, pengayaan diberikan oleh guru sejalan dengan pengajaran perbaikan. Siswa diberikan soal-soal latihan ataupun melaksanakan ulangan kembali dimana saat mengerjakan soal bagi siswa yang nilainya masih dibawah standar bisa menjadi kegiatan pengajaran perbaikan dan bagi siswa yang nilainya sudah baik bisa menjadi kegiatan pengayaan untuk memperdalam materi pelajaran yang telah didapat. Selain itu guru hanya meminta siswa untuk membaca serta mempelajari pokok bahasan atau materi selanjutnya.

Selain itu guru menciptakan suasana pembelajaran yang menyenangkan dengan menerapkan metode pembelajaran grouping atau belajar kelompok di kelas untuk meningkatkan motivasi belajar siswa. Dalam meningkatkan keterampilan belajar, guru meminta siswa untuk membuat catatan atau ringkasan dari materi yang disampaikan. Selain itu guru meminta siswa untuk mengerjakan latihanlatihan soal dan di tingkatkan saat siswa akan menghadapi ujian. Dalam mengembangkan sikap dan kebiasaan belajar yang baik, guru menekankan pada pemberian motivasi belajar. Selain itu guru menerapkan metode pembelajaran yang tepat agar siswa semangat dalam belajar walaupun metode yang diterapkan oleh guru itu hanya belajar kelompok atau grouping. Tidak lupa guru membiasakan siswa untuk selalu mengerjakan tugas-tugas yang diberikan secara teratur. Dalam melaksanakan layanan bimbingan belajar, guru mengalami hambatan pada keterbatasan waktu.

Hambatan itu muncul saat guru harus mengelola waktu antara harus mencapai tujuan penyampaian materi dengan pelaksanaan layanan bimbingan belajar. Selain itu keterbatasan pemahaman dan kemampuan guru menjadi salah satu kendala. Dalam melaksanakan layanan bimbingan belajar, guru melakukannya sesuai dengan kemampuan dan pemahaman mereka. Selain itu guru mengalami kendala dalam mengukur keterlaksanaan layanan bimbingan belajar yang telah diberikan karena belum disusunnya program secara sistematis. Hambatan dalam melaksanakan pelayanan bimbingan dan konseling di SD adalah kemampuan guru kelas yang diikuti oleh sarana dan prasarana, waktu, kemauan, dan kerjasama, dan dana serta dukungan kepala sekolah.

\section{KESIMPULAN}

Berdasarkan hasil penelitian dan pembahasan yang diperoleh tentang pelaksanaan layanan bimbingan belajar pada siswa kelas IV SD Negeri 58 Tambana, dapat disimpulkan bahwa guru belum membuat program layanan bimbingan belajar. Layanan bimbingan belajar dilaksanakan oleh guru kelas IV sesuai dengan pemahaman guru tentang konsep layanan bimbingan belajar. Pelaksanaan layanan bimbingan belajar oleh guru dipahami sebagai suatu bentuk bantuan bagi siswa kelas IV untuk mencapai hasil belajar sesuai target yang ditetapkan dan bukan pada memperbaiki kesalahankesalahan dan kesulitan-kesulitan yang dihadapi siswa selama proses pembelajaran. Layanan bimbingan belajar dilaksanakan oleh guru namun belum sesuai konsep yang seharusnya. Dalam melaksanakan layanan bimbingan belajar, guru menggunakan metode perbaikan dan pengayaan. Sebagai pelaksana layanan bimbingan belajar, guru mengalami kendala pada keterbatasan pemahaman, waktu, dan keterampilan tentang layanan bimbingan belajar. Selain itu, keterbatasan fasilitas dan belum disediakannya biaya pelaksanaan menjadi salah satu faktor hambatan dalam melaksanakan layanan bimbingan belajar bagi siswa kelas IV. Dalam menggunakan metode layanan bimbingan belajar, guru mengalami hambatan pada keterbatasan pengetahuan tentang metodemetode yang harus digunakan. Selain itu guru mengalami kesulitan dalam mengkombinasikan antara metode pembelajaran dengan metode bimbingan belajar. 


\section{Daftar Pustaka}

Achmad J. Nurihsan \& Sudianto. 2012. Manajemen Bimbingan Konseling di SD/MI Kurikulum. Jakarta: Grasindo.

Badarudin. 2011. Modul Bimbingan dan Konseling di Sekolah Dasar. Diakses dari https://ayahalby.files.wordpress.com/2012/10/modul-bimbingan-konseling-badar.pdf. pada tanggal 25 Februari 2020, jam 13:01 WIB.

Hikmawati. 2011. Metode Penelitian Kualitatif Dalam Pendidikan dan Bimbingan Konseling. Jakarta: Rajawali Pers.

M. Nurul Iman 2015. "Penggunaan Layanan Bimbingan Kelompok Untuk Meningkatkan Motivasi Belajar Pada Siswa Kelas VIII SMP Negeri 1 Bandar Sribhawono Kabupaten Lampung Timur.

Nur Amelia 2017. "Pengaruh Bimbingan Belajar Terhadap Hasil Belajar Peserta Didik Kelas IV SD Inpres Batangkaluku Kabupaten Gowa.

Peraturan Menteri Pendidikan dan Kebudayaan Republik Indonesia Nomor 11 Tahun 2014.

Prayitno \& Erman Amti. 2004. Dasar-Dasar Bimbingan dan Konseling. Jakarta: Rineka Cipta.

Salahudin, Anas. 2010. Bimbingan dan Konseling. Bandung: Pustaka Setia.

Sugiyono. 2008. Penelitian Kuantitatif Kualitatif dan REDD. Bandung: Alfabeta.

Tohirin. 2009. Bimbingan dan Konseling di Sekolah dan Madrasah (Berbasis Integrasi). Jakarta: Rajawali Pers.

Undang-undang No. 20 Tahun 2003 Tentang Sistem Pendidikan Nasional. Diakses dari http://kemenag.go.id/file/dokumen/UU2003.pdf. pada tanggal 25 Februari 2020, jam 02:20 WIB. 